\title{
Cadmium transport and tolerance in rice: perspectives for reducing grain cadmium accumulation
}

\author{
Shimpei Uraguchi* and Toru Fujiwara
}

\begin{abstract}
Cadmium (Cd) is a toxic heavy metal which harms human health. In Japan, a major source of human Cd-intake is rice grains and contamination of paddy soils by $\mathrm{Cd}$ and accumulation of $\mathrm{Cd}$ in rice grains are the serious agricultural issues. There also exist $\mathrm{Cd}$ contamination of rice and its toxicity in several populations in countries including China and Thailand. Understanding the $\mathrm{Cd}$ transport mechanisms in rice can be a basis for regulating rice $\mathrm{Cd}$ transport and accumulation by molecular engineering and marker-assisted breeding. Recently, a number of studies have revealed the behavior of $\mathrm{Cd}$ in rice, genetic diversity of $\mathrm{Cd}$ accumulation, quantitative trait loci controlling $\mathrm{Cd}$ accumulation and transporter molecules regulating $\mathrm{Cd}$ accumulation and distribution in rice. In this article, we summarize recent advances in the field and discuss perspectives to reduce grain $\mathrm{Cd}$ contents.
\end{abstract}

\section{Introduction}

Cadmium $(\mathrm{Cd})$ is a toxic heavy metal and is also known as one of the major environmental pollutants. Moderate $\mathrm{Cd}$ contamination of arable soils can result in considerable $\mathrm{Cd}$ accumulation in edible parts of crops (Arao and Ae 2003; Arao et al. 2003; Wolnik et al. 1983). Such levels of Cd in plants are not toxic to crops but can contribute to substantial Cd dietary intake by humans (Wagner 1993). In the case of "Itai-itai disease", Cd-polluted rice was the major source of $\mathrm{Cd}$ intake in the patients (Yamagata and Shigematsu 1970). This is the early case of chronic Cd toxicity in general populations without specific industrial exposure. Even in recent general populations in Japan, the internal Cd level is higher than those of other countries and this is largely because of daily consumption of Japanese rice which contains relatively high Cd (Watanabe et al., 1996; Watanabe et al. 2000; Tsukahara et al. 2003). $\mathrm{Cd}$ concentrations of recent Japanese rice have been constantly higher compared to those of other countries (Watanabe et al., 1996; Shimbo et al., 2001), although the values are much lower than the limit established by the Codex Alimentarius Commission of FAO/WHO $(0.4 \mathrm{mg} / \mathrm{kg})$. In some areas in China and Thailand,

\footnotetext{
* Correspondence: shim@bu.iij4u.or.jp

Graduate School of Agricunltural and Life Sciences, The University of Tokyo,
} Tokyo 113-8657, Japan production of highly Cd-polluted rice and renal disfunctions among populations were reported (Nordberg et al., 1997; Jin et al., 2002; Honda et al., 2010). In the United States, increased consumption of rice and other cereals contributes to the recent increase of the dietary Cd intake (Egan et al. 2007). Many reports suggest importance to consider chronic effects of $\mathrm{Cd}$ exposure through foods (Jarup and Akesson 2009). In Japanese populations, the average dietary $\mathrm{Cd}$ intake $(3.0 \mu \mathrm{g} \mathrm{Cd} / \mathrm{kg}$ body weight/ week) exceeds the tolerable weekly intake $(2.5 \mu \mathrm{g} \mathrm{Cd} / \mathrm{kg}$ body weight) set by the European Food Safety Authority (EFSA) and is about $50 \%$ of a provisional tolerable monthly intake ( $25 \mu \mathrm{g} \mathrm{Cd} / \mathrm{kg}$ body weight/month) established by the Joint Food and Agriculture Organization/ World Health Organization (FAO/WHO) Expert Committee on Food Additives and Contaminants (JECFA). Reeves and Chaney (2008) suggested to consider the high $\mathrm{Cd}$ availability of rice for humans because of relatively low iron and zinc contents in rice-based foods (Reeves and Chaney, 2008). These suggest the importance of reducing grain $\mathrm{Cd}$ accumulation in rice and other cereals for better human health.

Recently, as a model plant of cereals, physiological and molecular understanding of $\mathrm{Cd}$ transport in rice plants have been advanced. In this review, we describe current knowledge of rice $\mathrm{Cd}$ transporters and their (possible)

\section{空 Springer}

(C) 2012 Uraguchi and Fujiwara; licensee Springer. This is an Open Access article distributed under the terms of the Creative Commons Attribution License (http://creativecommons.org/licenses/by/2.0), which permits unrestricted use, distribution, and reproduction in any medium, provided the original work is properly cited. 
roles in Cd accumulation. Several trials to generate "low-Cd-rice" based on these findings are also described.

\section{Physiology of rice $\mathrm{Cd}$ accumulation}

The average $\mathrm{Cd}$ concentration in Japanese soils is 0.2 $0.3 \mathrm{mg} / \mathrm{kg}$ DW (Takeda et al. 2004), which is somewhat higher than those of agricultural soils in China, Indonesia and the United States (Holmgren et al., 1993; Herawati et al., 2000). In paddy soils largely affected by industrial activities like mining and smelter, the Cd concentrations are much higher than the average (Xian, 1988; Asami et al., 1995). In agricultural soils, atmospheric deposition (Keller and Schulin, 2003) is known as a major source of $\mathrm{Cd}$ input. In paddy fields, irrigation water is another $\mathrm{Cd}$ source which continuously loads $\mathrm{Cd}$ into soils (Kikuchi et al. 2007).

Rice absorbs $\mathrm{Cd}^{2+}$ in soils, and after several processes of transport $\mathrm{Cd}$ finally accumulates into grains. $\mathrm{Cd}$ is rapidly transported from roots to shoots by the xylem after absorption (Uraguchi et al. 2009b). Substantial Cd is detected in the xylem sap and shoot tissues $1 \mathrm{~h}$ after $\mathrm{Cd}$ treatment to roots, and this activity of root-to-shoot translocation by the xylem is the determinant for shoot $\mathrm{Cd}$ accumulation level. On the other hand, in the panicle neck, phloem is the major $\mathrm{Cd}$ transport route into grains (Tanaka et al. 2007). In phloem sap, Cd binds to an unknown $13 \mathrm{kDa}$ protein and $\mathrm{SH}$-compounds (Kato et al. 2010). The real-time live-imaging technique using a positron emitting radio isotopes called PETIS revealed the detailed behavior of $\mathrm{Cd}$ in rice after absorption (Fujimaki et al. 2010). They demonstrated that $\mathrm{Cd}$ is rapidly translocated from roots to shoots through culms and $\mathrm{Cd}$ tends to be retained in nodes. And after $7 \mathrm{~h}$ of $\mathrm{Cd}$ treatment, $\mathrm{Cd}$ is preferentially deposited into panicles rather than into leaf blades. These suggest that nodes are the important tissue for redirecting $\mathrm{Cd}$ transport from roots probably by transferring $\mathrm{Cd}$ from xylem to phloem. In addition to $\mathrm{Cd}$ absorbed from roots, remobilization of $\mathrm{Cd}$ in leaf blades is also likely to contribute to grain $\mathrm{Cd}$ accumulation (Rodda et al. 2011). They suggest that a substantial amount of $\mathrm{Cd}$ accumulated in leaf blades before heading is remobilized and transported into grains during the ripening stage.

These physiological studies indicate four major transport processes for rice $\mathrm{Cd}$ accumulation: (1) root $\mathrm{Cd}$ uptake, (2) root-to-shoot translocation by xylem flow, (3) redirection at nodes and (4) remobilization from leaves (Figure 1). After the first report by Ishikawa et al. (2005), several studies conducted QTL analyses to identify the responsible transporter gene for these processes (Ishikawa et al. 2010; Ishikawa et al. 2005; Tezuka et al. 2010; Ueno et al. 2009). QTL analysis is a very useful approach because there is a clear genotypic difference in $\mathrm{Cd}$ accumulation in shoots and grains among cultivars.
Generally, Cd accumulation in shoots and grains are potentially higher in indica cultivars compared to japonica cultivars (Arao and Ae 2003; He et al., 2006b; Uraguchi et al. 2009b) and moreover, some specific cultivars among indica rice accumulate much higher $\mathrm{Cd}$ in vegetative tissues and grains (Uraguchi et al. 2009b). Recently, several transporters have been identified as a $\mathrm{Cd}$ transporter in rice by forward and reverse genetics and their functions in these processes will be reviewed in the following sections and summarized in Figure 1.

\section{Uptake by roots}

In plants and mammals, many of transporters for divalent transition metals have a $\mathrm{Cd}^{2+}$ uptake activity. In mammals, ZIP8 and ZIP14, two transporters belonging to the Zinc-regulated transporter (ZRT) -like, Iron-regulated transporter (IRT) -like protein (ZIP) family, transport $\mathrm{Cd}^{2+}$ as well as $\mathrm{Mn}^{2+}, \mathrm{Fe}^{2+}$ and $\mathrm{Zn}^{2+}$ (He et al. 2006a; Himeno et al. 2009; Nebert et al. 2009). In plants, it has been demonstrated much earlier than in mammals that AtIRT1, a ZIP family transporter for $\mathrm{Fe}^{2+}, \mathrm{Zn}^{2+}$ and $\mathrm{Mn}^{2}$ ${ }^{+}$also mediates Cd uptake in roots of Arabidopsis thaliana (Connolly et al. 2002; Vert et al. 2002). AtIRT1 is the primary transporter for the strategy-1 iron $\left(\mathrm{Fe}^{2+}\right)$ uptake system in A. thaliana. In rice, iron is mainly absorbed by the strategy-2 system in the form of Fe-phytosiderophore (Romheld and Marschner 1986), but $\mathrm{Fe}^{2+}$ transporters have been also identified which may function in $\mathrm{Fe}^{2+}$ uptake by roots (Ishimaru et al. 2006). OsIRT1 and OsIRT2 have an influx activity of $\mathrm{Cd}^{2+}$ as well as $\mathrm{Fe}^{2+}$ in yeasts, suggesting that OsIRTs play some role in root $\mathrm{Cd}$ uptake especially after release of pounded water during intermittent water management (Ishimaru et al. 2006; Nakanishi et al. 2006). They suggested that under flooded paddy soils, OsIRTs might be induced by lower levels of available iron and after water release induced OsIRTs might contribute to uptake of $\mathrm{Cd}$ which was much available in aerobic conditions. When OSIRT1 was overexpressed, $\mathrm{Cd}$ accumulation in roots and shoots was increased under MS medium containing excess $\mathrm{Cd}$, but this phenotype was not observed in the field condition (Lee and An 2009). These suggest that OsIRT1 is potentially involved in root $\mathrm{Cd}$ uptake but its contribution is largely affected by the environmental (soil) conditions.

Transporters of natural resistance-associated macrophage protein (Nramp) family are also known to mediate Cd transport. In mammals, DCT1/DMT1/Nramp2 functions in $\mathrm{Cd}^{2+}$ uptake as well as uptake of $\mathrm{Zn}, \mathrm{Mn}, \mathrm{Fe}, \mathrm{Co}$ and $\mathrm{Ni}$ ions (Gunshin et al. 1997; Hosoyamada et al. 2003). In plants, at the same time, it has been demonstrated that AtNramp1, AtNramp3 and AtNramp4 mediate inward $\mathrm{Cd}$ transport in yeasts and overexpression of AtNramp3 resulted in increased sensitivity to $\mathrm{Cd}$ (Thomine et al. 2000). In rice, there are seven Nramp 


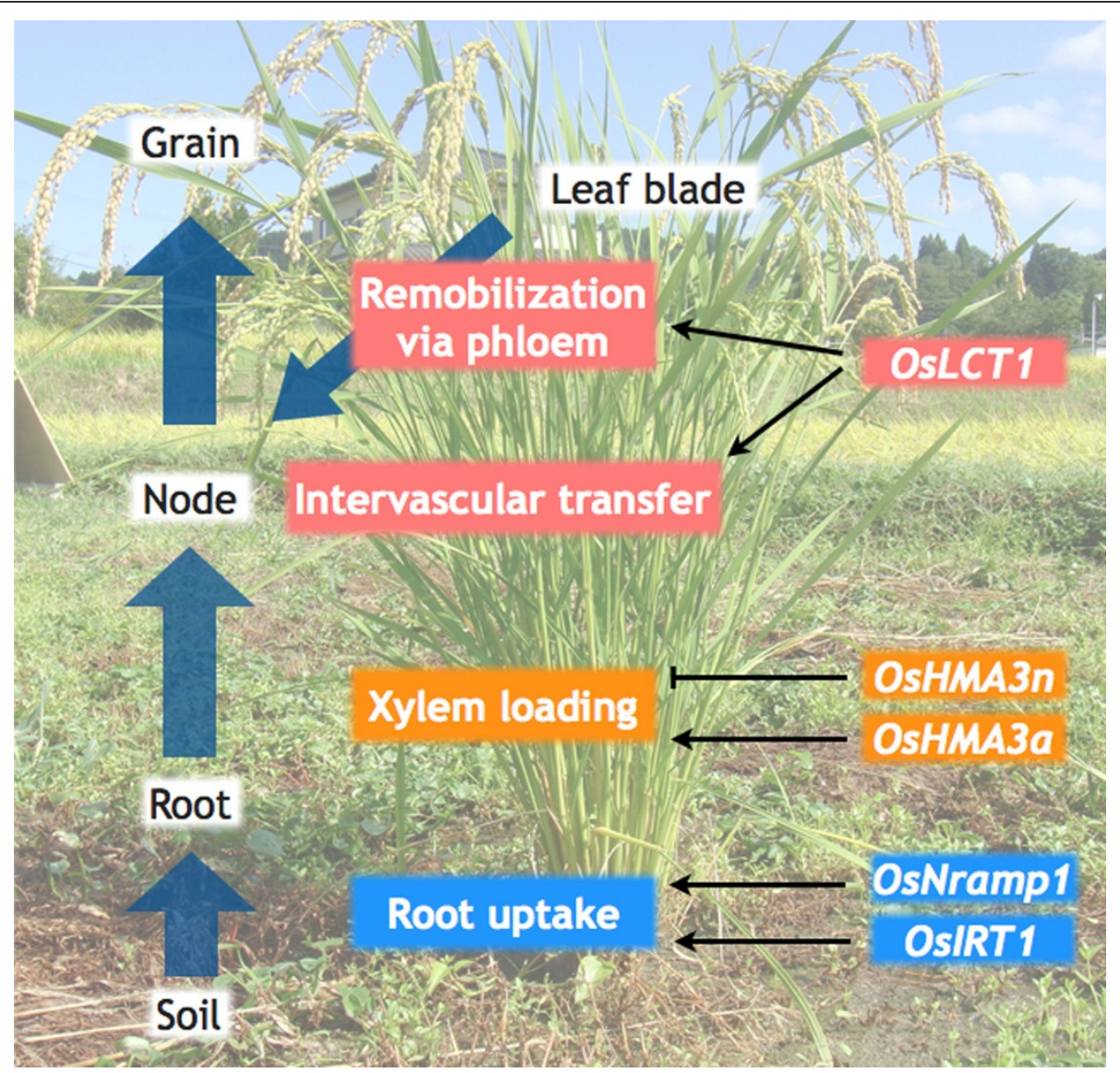

Figure $1 \mathrm{~A}$ schematic model of $\mathrm{Cd}$ transport processes from soil to grains in rice. $\mathrm{Cd}$ is absorbed from soils into roots. OsIRT1 and OsNramp1 are suggested to mediate this process. OsHMA3n (the functional allele of OsHMA3) play a critical role in Cd compartmentation into vacuoles in root cells and thus negatively regulates $\mathrm{Cd}$ xylem loading. OsHMA3a (the non-functional allele of OsHMA3) can not function in vacuolar $\mathrm{Cd}$ compartmentation in roots and which results in high efficiency of root-to-shoot Cd translocation. OsLCT1 contributes to Cd remobilization from leaf blades via phloem and also is likely to play a part in intervascular $\mathrm{Cd}$ transfer at nodes.

genes. OsNramp1, an iron transporter, has been established as a Cd-influx transporter in the plasma-membrane (Takahashi et al. 2011). The cell-type specificity of $O s N$ ramp1 expression was not examined but the mRNA expression was much higher in roots than in shoots. OsNramp1-overexpressing rice plants accumulated less $\mathrm{Cd}$ in roots and much $\mathrm{Cd}$ in shoots compared to the wild-type plants when grown in media containing $1 \mu \mathrm{M}$ or less $\mathrm{Cd}$, suggesting that OsNramp1 is possibly involved in $\mathrm{Cd}$ transport into roots. Much interesting finding of their report is higher expression of OsNramp1 in indica cultivars. Comparing Sasanishiki (a japonica cultivar) and Habataki (a indica cultivar), the root-to-shoot Cd translocation ability is greater in Habataki (Uraguchi et al. 2009b). Following QTL analysis of a mapping population obtained by crossing the two cultivars, a major QTL for high $\mathrm{Cd}$ accumulation in shoots of Habataki was detected on the short arm of Chr. 7 (Ishikawa et al. 2010). Although the responsible gene has not been identified, this QTL contains OsNramp1. There was no difference in the amino acid sequences of OsNramp1 between Habataki and Sasanishiki, but the gene expression was higher in Habataki and other indica cultivars probably caused by several insertion and deletion in the promoter region (Takahashi et al. 2011). This higher expression of OsNramp1 in indica cultivars may partly explain higher $\mathrm{Cd}$ accumulation in shoots of indica rice independent from the effect of OsHMA3, another Cd transporter described in the next section.

\section{Xylem loading and root-to-shoot translocation}

The ability of xylem-mediated $\mathrm{Cd}$ translocation into shoots is shown as a major determinant for shoot $\mathrm{Cd}$ accumulation in many plants including rice (Hart et al. 2006; Mori et al. 2009; Uraguchi et al. 2009b). In A. thaliana and $A$. halleri (a $\mathrm{Cd} / \mathrm{Zn}$ hyperaccumulator), the key transporters for xylem $\mathrm{Cd}$ transport have been first identified. In A. thaliana, the $\mathrm{P}_{1 \mathrm{~B}}$-type ATPase 
AtHMA2 and AtHMA4 regulate root-to-shoot translocation of $\mathrm{Cd}$ and $\mathrm{Zn}$ (Hussain et al. 2004; Verret et al. 2004; Wong and Cobbett 2009). In A. halleri, AhHMA4, a homolog of AtHMA4 plays a critical role in translocation of $\mathrm{Cd}$ and $\mathrm{Zn}$ into shoots (Hanikenne et al. 2008). The enhanced promoter activity and increased gene copy number of $A h H M A 4$ result in higher expression of AhHMA4 in root stele and contribute to hyperaccmulation and hypertolerance of $\mathrm{Cd}$ and $\mathrm{Zn}$ in A. halleri.

Following the identification of the genes for xylem $\mathrm{Cd}$ transport in A. thaliana and A. halleri, OsHMA3 has been identified as a regulator for xylem $\mathrm{Cd}$ transport in rice by mediating vacuolar sequestration of $\mathrm{Cd}$ in root cells (Miyadate et al. 2011; Ueno et al. 2010). Compared to AtHMA4 and AhHMA4, OsHMA3 has some unique features. All these HMAs mediate Cd efflux transport, but OsHMA3 reportedly does not transport other metals such as $\mathrm{Zn}$, whereas AtHMA4 and AhHMA4 functions in both $\mathrm{Zn}$ and $\mathrm{Cd}$ transport. Subcellular localization also differs between OsHMA3 and others. OsHMA3 is suggested to be localized to the vacuolar membrane, but AtHMA4 and AhHMA4 are localized to the plasma-membrane. The major difference of OsHMA3 and Arabidopsis HMA4s is the physiological function in plants. In the Nipponbare background, RNAi-mediated knock-down of OsHMA3 increased root-to-shoot $\mathrm{Cd}$ translocation and the overexpression reduced shoot $\mathrm{Cd}$ accumulation (Ueno et al. 2010). They suggests that in Nipponbare, OsHMA3 functions in vacuolar compartmentation of $\mathrm{Cd}$ in root cells and hence reduces the xylem loading of $\mathrm{Cd}$ and subsequent shoot $\mathrm{Cd}$ accumulation (Ueno et al., 2010), whereas AtHMA4 and AhHMA4 facilitate loading of $\mathrm{Cd}$ into the xylem. This finding reveals the mechanism for limiting $\mathrm{Cd}$ translocation into shoots in japonica rice.

At the same time, they found a single amino acid substitution in OsHMA3 from some indica cultivars (Anjana Dhan, Cho-ko-koku and Jarjan) which results in the lossof-function (Miyadate et al. 2011; Ueno et al. 2011; Ueno et al. 2010). These cultivars show remarkably high $\mathrm{Cd}$ accumulation in shoots and grains even compared to other indica cultivars under the moderately Cd contaminated soil and the non-Cd-contamintation soil (Uraguchi et al. 2009b). Imaging analyses using PETIS demonstrated more rapid and greater $\mathrm{Cd}$ translocation from root-toshoot in these Cd-high-accumulating cultivars (Ishikawa et al., 2011). The loss-of-functional allele of OsHMA3 is responsible for exceedingly higher root-to-shoot $\mathrm{Cd}$ translocation in these cultivars, because the non-functional OsHMA3 may result in failure of Cd compartmentation into vacuoles in root cells (Miyadate et al. 2011; Ueno et al. 2011; Ueno et al. 2010). This allele has not been detected in several japonica cultivars and also other indica cultivars such as Habataki (Takahashi et al. 2011), suggesting that this OsHMA3 is not the casual gene for general difference in $\mathrm{Cd}$ accumulation between indica and japonica rice.

\section{Phloem transport into grains}

There has been no report of transporters for phloem $\mathrm{Cd}$ transport in plants so far, although in rice, phloem mediates nearly $100 \%$ of the $\mathrm{Cd}$ deposition into grains (Tanaka et al. 2007). Xylem-to-phloem Cd transfer at nodes is suggested (Fujimaki et al. 2010) and phloem Cd transport through a panicle neck shows genotypic variation (Kato et al. 2010). These suggest the existence and involvement of transporters at nodes for phloem $\mathrm{Cd}$ transport into grains. Remobilization of $\mathrm{Cd}$ from leaf blades to grains (Rodda et al. 2011) also appears to be mediated by phloem transport.

Recently, we have identified a transporter gene involved in phloem Cd transport (Uraguchi et al. 2011). This rice gene, named OsLCT1, is the homolog of wheat Low-affinity Cation Transporter1 (Clemens et al. 1998), and encodes a Cd-efflux transporter on the plasma-membrane. OsLCT1 expression was higher in leaf blades and nodes during reproductive stages. Especially in node I, the uppermost node, OsLCT1 was mainly expressed in diffuse vascular bundles which connected to panicles. In the Nipponbare background, Cd levels in grains and phloem exudate from leaf blades were substantially reduced in RNAi plants compared to control plants, although $\mathrm{Cd}$ concentration in xylem sap did not differ. These results suggest that OsLCT1 in leaf blades functions in Cd remobilization by phloem, and in node I, OsLCT1 is likely to play a part in intervascular $\mathrm{Cd}$ transfer from enlarged large vascular bundles to diffuse vascular bundles, which connect to the panicle. This is the first identification of a transporter for phloem $\mathrm{Cd}$ transport in plants.

\section{Other genes related to $\mathrm{Cd}$ accumulation and tolerance}

In addition to the transporters involved in long-distance $\mathrm{Cd}$ transport processes described above, rice genes related to excess $\mathrm{Cd}$ stress have been reported. These genes might function in subcellular $\mathrm{Cd}$ transport such as exclusion of $\mathrm{Cd}$ from cytoplasm to apoplast and compartmentation into vacuoles as well as damage repairing processes that appear to be a mechanism underlying plant $\mathrm{Cd}$ tolerance (Clemens 2001; Uraguchi et al. 2009a). In this section, recent findings of rice genes possibly functioning in $\mathrm{Cd}$ homeostasis are reviewed. Although understanding of $\mathrm{Cd}$ tolerance may not directly contribute to advance establishment of "low-Cd-rice", the genes related to Cd tolerance may be potentially applied to manipulate rice $\mathrm{Cd}$ accumulation by regulating such as subcellular $\mathrm{Cd}$ transport.

Several ATP-binding cassette $(\mathrm{ABC})$ proteins are suggested to mediate vacuolar compartmentation of $\mathrm{Cd}$ glutathione and/or phytochelatin (PC) conjugates in baker's yeasts ( $\mathrm{Li}$ et al. 1997), fission yeasts (Prévéral et al. 
2009), the worm Caenorhabditis elegans (Vatamaniuk et al. 2005) and A. thaliana (Park et al. 2012). A member of ABC proteins of human (Tommasini et al. 1996) and A. thaliana (Kim et al. 2007) functions in Cd extrusion from the cytoplasm. We have recently reported that rice OsPDR5/ABCG43 is likely to encode an ABC-type protein for cellular Cd tolerance (Oda et al. 2011). The transcript of $A B C G 43$ was remarkably induced in rice roots by $\mathrm{Cd}$ treatments, suggesting a possible involvement of ABCG43 in $\mathrm{Cd}$ tolerance in rice, although detailed mechanisms should be further investigated. A rice transporter for a $\mathrm{Cd}$ PC conjugate would be also further identified, as demonstrated in A. thaliana (Park et al. 2012).

There are reports of rice genes for new mechanisms of $\mathrm{Cd}$ tolerance. A novel rice gene Low cadmium ( $L C D)$ is involved in $\mathrm{Cd}$ accumulation and tolerance (Shimo et al. 2011). Knock-out of $L C D$ resulted in reduced Cd accumulation and increased growth under excess Cd. But LCDGFP was localized to the cytoplasm and nucleus, suggesting that LCD is not a membrane-transporter. $L C D$ is not homologous to any other genes, and the authors concluded that LCD is a novel protein related to Cd homeostasis. Kuramata et al. (2009) reported that a novel cysteine-rich peptides encoded by $O s C D T 1$ is possibly involved in rice $\mathrm{Cd}$ tolerance. Overexpression of OsCDT1 in A. thaliana increased the growth of plants under $\mathrm{Cd}$ exposure (Kuramata et al. 2009).

These reports indicate that novel mechanisms mediated by unknown molecules functions in $\mathrm{Cd}$ tolerance in plants and also indicate that rice is a potential genetic material for mining new genes related to $\mathrm{Cd}$ stress and/or accumulation. We have screened mutant populations and various genotypes and found several Cd-sensitive lines (Figure 2a) and one Cd-tolerant line (Figure $2 \mathrm{~b}$ ). Because there exist few examples of $\mathrm{Cd}$-tolerant lines, analyses of these lines would contribute to advance understanding of $\mathrm{Cd}$ toxicity and tolerance in organisms.

\section{Approaches for reducing grain $\mathrm{Cd}$ accumulation}

Considering substantial contribution of $\mathrm{Cd}$ in rice grains to higher $\mathrm{Cd}$ intake in Asian people, reducing $\mathrm{Cd}$ pollution of paddy fields and rice grain $\mathrm{Cd}$ accumulation are major issues to the field of agricultural science. Not only in the case of "Itai-itai disease" in Japan, but in some areas in China and Thailand, there are reports of Cd contamination of paddy soils and rice grains and renal disfunction in the populations (Nordberg et al., 1997; Jin et al., 2002; Honda et al., 2010). In Japan, the Ministry of Agriculture, Forestry, and Fisheries of Japan encourages rice growers to keep paddy fields flooded before and after heading to reduce $\mathrm{Cd}$ uptake by rice in $\mathrm{Cd}$-contaminated areas. This is based on the fact that under the flooded condition, the soil is under a reductive condition and a large part of $\mathrm{Cd}$ in the soil forms $\mathrm{CdS}$ with low solubility (Iimura and Ito 1978). On the other hand, once the field is drained, the soil becomes an oxidative condition and $\mathrm{CdS}$ in the soil is changed to $\mathrm{Cd}^{2+}$ which is much available to plants (Ito and Iimura 1976). This flooding water

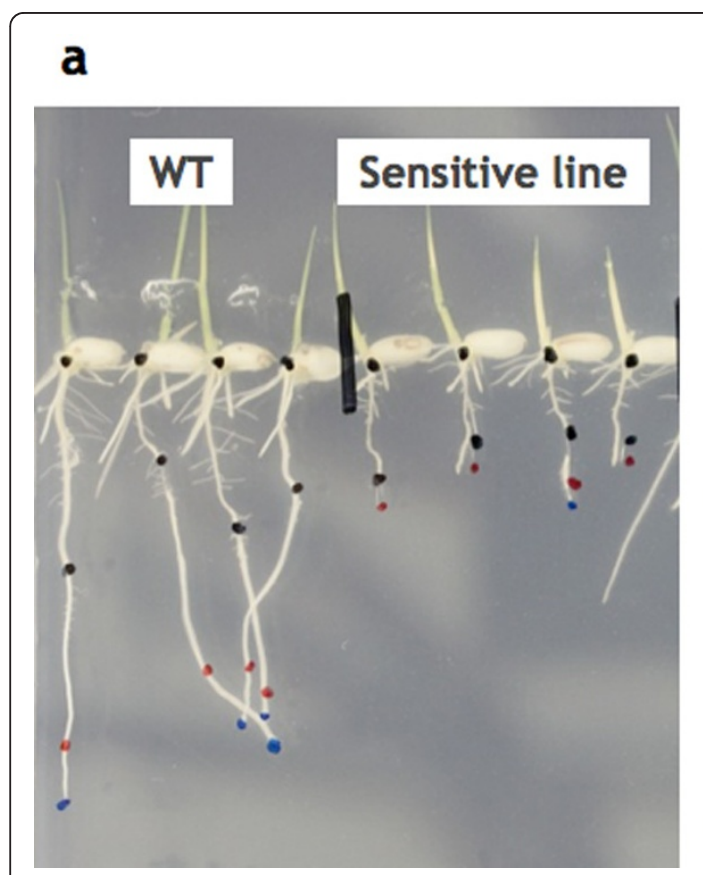

\section{b}

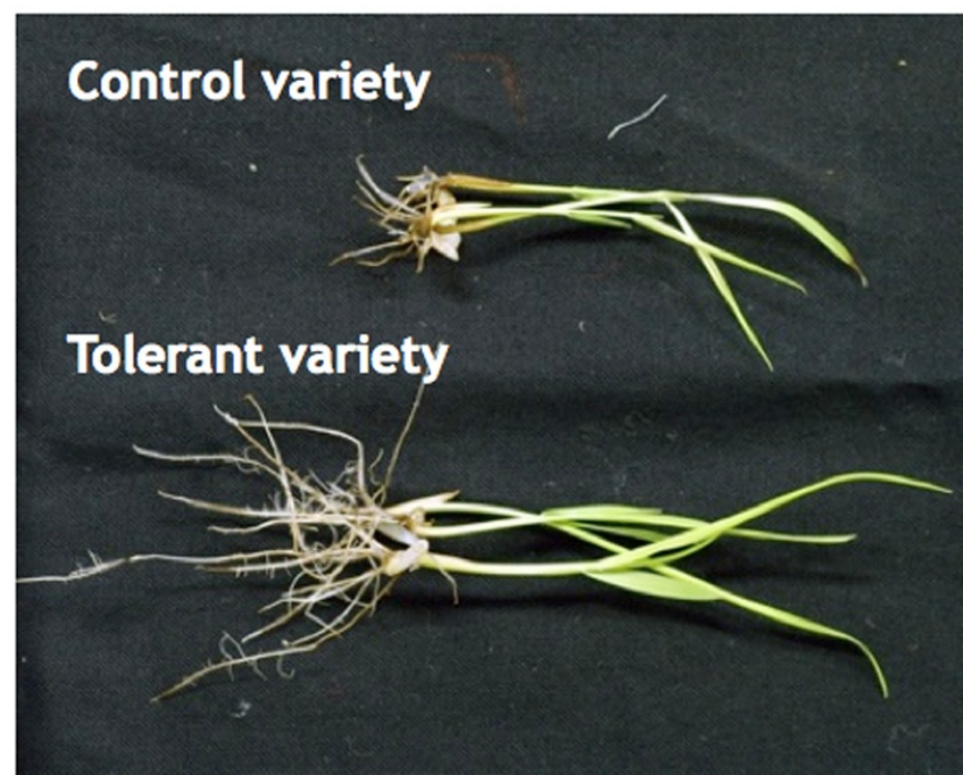

Figure 2 Examples of a Cd-sensitive line (a) and a Cd-tolerant cultivar (b). These plants show different phenotypes under excess $\mathrm{Cd}$ treatments. 
management before and after heading drastically reduces grain $\mathrm{Cd}$ concentrations, but on contrary, this treatment increases arsenic concentration in grains (Arao et al. 2009). Moreover, it seems difficult to uniform the flooding condition through entire paddy fields during the treatment, which may partially fail in reducing $\mathrm{Cd}$ availability in soils. Soil removal, replacement and soil inversion are possible other options and these have been conducted in some highly $\mathrm{Cd}$-polluted paddy areas in Japan. This method is a quick solution for the contamination, but is cost-ineffective and requires a large amount of alternative soils. These features make it unpractical to apply this method to a much larger areas of paddies with moderate $\mathrm{Cd}$ contamination. Alternatively, several approaches to clean-up moderately Cd-polluted paddy soils have been suggested. Phytoextraction using the high-Cd-accumulating cultivar such as Cho-ko-koku (Murakami et al. 2009) and chemical washing of soils using ferric chloride (Makino et al. 2008) are possible methods in terms of efficiency, cost and environmental effects.

In combination to these soil remediation methods, establishment of "low-Cd-rice" based on genetic and molecular findings is expected as a promising approach to reduce human Cd intake. Regulation of Cd transporters by the transgenic technique has been used successfully to reduce $\mathrm{Cd}$ accumulation in rice plants. Overexpression of a functional allele of OsHMA3 in Nipponbare background resulted in drastic reduction of grain $\mathrm{Cd}$ concentration under a soil with relatively high Cd concentration (1.5 mg/kg) (Ueno et al. 2010). These OsHMA3 overexpressing rice reported in their manuscript did not show any reduction in zinc and iron contents in grains, although the growth of the plants was not reported. This phenotype is noteworthy because zinc and iron are important minerals for human. However, Cd accumulation of these OsHMA3 overexpressing rice under moderate or slight $\mathrm{Cd}$ contamination often observed in fields should be examined further.

Knock-down of OsLCT1 also reduced grain Cd by $50 \%$ under the soil containing $0.2 \mathrm{mg} \mathrm{Cd} / \mathrm{kg}$ (Uraguchi et al. 2011). This soil Cd concentration is comparable to the average of Cd levels in Japanese soils, suggesting the significant potential of OsLCT1 alleles in establishing a rice cultivar which accumulates less $\mathrm{Cd}$ in grain under soils with slight $\mathrm{Cd}$ contamination. Importantly, the growth and mineral contents in grains were not negatively affected in these OsLCT1-knockdown plants.

These studies are good examples of the molecular approach based on physiological observations. Xylem loading and phloem transport are both shown as important transport processes determining grain $\mathrm{Cd}$ accumulation and the regulation of the responsible genes for the respective process enables reducing grain Cd levels without affecting quantity and quality of products. But one of the further issues for marketing "low-Cd-rice" in Japan is to establish "low-Cd-rice" by a non-transgenic approach. In Japan, the present consumers largely prefer non-transgenic agricultural products rather than those of genetically modified plants. Screening non-functional allele of OsLCT1 from chemically or radiation mutagenized populations with a background of major cultivars such as Koshihikari and establishing "low-Cd Koshihikari" is a possible practical approach. Another possible strategy is a marker-assisted breeding. For example, identification of a QTL for low-Cd-accumulation from a low-Cd-accumulating cultivar will enable to establish "low-Cd Koshihikari" by introducing the low-Cd QTL into Koshihikari by a marker-assisted breeding.

Manipulation of transporter genes expression also enables to generate high-Cd-accumulating rice. Overexpression of OsNramp1 (Takahashi et al. 2011) and OsIRT1 (Lee and An 2009) increased shoot Cd accumulation in rice plants. Knock-down of OsHMA3 also increased rootto-shoot Cd translocation (Ueno et al. 2010). These high$\mathrm{Cd}$-accumulating plants will be applied to remove $\mathrm{Cd}$ from Cd-polluted paddy soils (phytoextraction). Abe et al. (2011) introduced a non-functional allele of OsHMA3 from a high-Cd-accumulating cultivar Jarjan into Koshihikari by marker-assisted selection. These plants with a Jarjan allele of OsHMA3 showed a good Cd-removing ability from soils in a background of Koshihikari (Abe et al. 2011). They demonstrated that marker-assisted selection enabled to generate a high-Cd-accumulating rice with resistance to shattering and lodging and with larger biomass. These plants will increase the efficiency of phytoextraction operation in the field compared to using the high-Cd-accumulating rice such as Cho-ko-koku and Jarjan.

\section{Conclusions}

Within the last few years, understanding of Cd transport and identification of the responsible genes in rice have been largely advanced. But it is possible that unknown transporters or other molecules are involved in rice $\mathrm{Cd}$ transport and tolerance. Moreover, mining of useful alleles is essential to establish non-transgenic low/high$\mathrm{Cd}$-accumulating rice. The progress of understanding and application in rice regarding $\mathrm{Cd}$ transport may be extended to other cereals.

\section{Acknowledgements}

This work was supported in part by grants from the Japanese Society for the Promotion of Science to S.U. (22-8989) and from the Ministry of Agriculture, Forestry, and Fisheries of Japan to T.F. (Genomics for Agricultural Innovation Grant IPG-0005). 


\section{Authors' contributions}

SU and TF wrote the manuscript. Both authors have read and approved the final manuscript.

\section{Competing interests}

The authors declare that they have no competing interests.

\section{Received: 14 October 2011 Accepted: 27 February 2012}

Published: 27 February 2012

\section{References}

Abe T, Taguchi-Shiobara F, Kojima Y, Ebitani T, Kuramata M, Yamamoto T, Yano M, Ishikawa S (2011) Detection of a QTL for accumulating Cd in rice that enables efficient $\mathrm{Cd}$ phytoextraction from soil. Breeding Sci 61:43-51. doi:10.1270/jsbbs.61.43.

Arao T, Ae N (2003) Genotypic variations in cadmium levels of rice grain. Soil Sci Plant Nutr 49:473-479. doi:10.1080/00380768.2003.10410035.

Arao T, Ae N, Sugiyama M, Takahashi M (2003) Genotypic differences in cadmium uptake and distribution in soybeans. Plant Soil 251:247-253. doi:10.1023/A:1023079819086.

Arao T, Kawasaki A, Baba K, Mori S, Matsumoto S (2009) Effects of water management on cadmium and arsenic accumulation and dimethylarsinic acid concentrations in Japanese rice. Environ Sci Tech 43:9361-9367. doi:10.1021/es9022738.

Asami T, Kubota M, Orikasa K (1995) Distribution of different fractions of cadmium, zinc, lead, and copper in unpolluted and polluted soils. Water Air Soil Poll 83:187-194. doi:10.1007/BF00477351.

Clemens S (2001) Molecular mechanisms of plant metal tolerance and homeostasis. Planta 212:475-486. doi:10.1007/s004250000458.

Clemens S, Antosiewicz DM, Ward JM, Schachtman DP, Schroeder II (1998) The plant CDNA LCT1 mediates the uptake of calcium and cadmium in yeast. PNAS 95:12043-12048. doi:10.1073/pnas.95.20.12043.

Connolly EL, Fett JP, Guerinot ML (2002) Expression of the IRT1 metal transporter is controlled by metals at the levels of transcript and protein accumulation. Plant Cell 14:1347-1357. doi:10.1105/tpc.001263.

Egan SK, Bolger PM, Carrington CD (2007) Update of US FDA's total diet study food list and diets. J Expo Sci Envi Epid 17:573-582. doi:10.1038/sj. jes.7500554.

Fujimaki S, Suzui N, Ishioka NS, Kawachi N, Ito S, Chino M, Nakamura S (2010) Tracing cadmium from culture to spikelet: noninvasive imaging and quantitative characterization of absorption, transport, and accumulation of cadmium in an intact rice plant. Plant Physiol 152:1796-1806. doi:10.1104/ pp.109.151035.

Gunshin H, Mackenzie B, Berger UV, Gunshin Y, Romero MF, Boron WF, Nussberger S, Gollan JL, Hediger MA (1997) Cloning and characterization of a mammalian proton-coupled metal-ion transporter. Nature 388:482-488. doi:10.1038/41343.

Hanikenne M, Talke IN, Haydon MJ, Lanz C, Nolte A, Motte P, Kroymann J, Weigel D, Krämer U (2008) Evolution of metal hyperaccumulation required cis-regulatory changes and triplication of HMA4. Nature 453:391-395. doi:10.1038/nature06877.

Hart JJ, Welch RM, Norvell WA, Kochian LV (2006) Characterization of cadmium uptake, translocation and storage in near-isogenic lines of durum wheat that differ in grain cadmium concentration. New Phytol 172:261-271. doi:10.1111/ j.1469-8137.2006.01832.x.

He L, Girijashanker K, Dalton KP, Reed J, Li H, Soleimani M, Nebert DW (2006a) ZIP8, member of the solute-carrier-39 (SLC39) metal-transporter family: characterization of transporter properties. Mol Pharmacol 70:171-180

He J, Zhu C, Ren Y, Yan Y, Jiang D (2006b) Genotypic variation in grain cadmium concentration of lowland rice. J Plant Nutr Soil Sci 169:711-716. doi:10.1002/ jpln.200525101.

Herawati N, Suzuki S, Hayashi K, Rivai IF, Koyama H (2000) Cadmium, copper, and zinc levels in rice and soil of Japan, Indonesia, and China by soil type. Bull Environ Contam Tox 64:33-39. doi:10.1007/s001289910006.

Himeno S, Yanagiya T, Fujishiro H (2009) The role of zinc transporters in cadmium and manganese transport in mammalian cells. Biochimie 91:1218-1222. doi:10.1016/j.biochi.2009.04.002.

Holmgren G GS, Meyer MW, Chaney RL, Daniels RB (1993) Cadmium, lead, zinc, copper, and nickel in agricultural soils of the United States of America. J Environ Qual 22:335-348
Honda R, Swaddiwudhipong W, Nishijo M, Mahasakpan P, Teeyakasem W, Ruangyuttikarn W, Satarug S, Padungtod C, Nakagawa H (2010) Cadmium induced renal dysfunction among residents of rice farming area downstream from a zinc-mineralized belt in Thailand. Toxicol Lett 198:26-32. doi:10.1016/j. toxlet.2010.04.023.

Hosoyamada M, Okubo M, Yamada K, Shibasaki T, Endou H (2003) Cadmium transport by human Nramp 2 expressed in Xenopus laevis oocytes. Toxicol Appl Pharm 187:162-167. doi:10.1016/50041-008X(02)00078-9.

Hussain D, Haydon MJ, Wang Y, Wong E, Sherson SM, Young J, Camakaris J, Harper JF, Cobbett CS (2004) P-Type ATPase heavy metal transporters with roles in essential zinc homeostasis in Arabidopsis. Plant Cell 16:1327-1339. doi:10.1105/tpc.020487.

limura K, Ito H (1978) Behavior and balance of contaminant heavy metals in paddy soils: Studies on heavy metal pollution of soils (Part 2). Bull Hokuriku Natl Agric Exp Stn 21:95-145

Ishikawa S, Abe T, Kuramata M, Yamaguchi M, Ando T, Yamamoto T, Yano M (2010) A major quantitative trait locus for increasing cadmium-specific concentration in rice grain is located on the short arm of chromosome 7. J Exp Bot 61:923-934. doi:10.1093/jxb/erp360.

Ishikawa S, Ae N, Yano M (2005) Chromosomal regions with quantitative trait loc controlling cadmium concentration in brown rice (Oryza sativa). New Phytol 168:345-350. doi:10.1111/j.1469-8137.2005.01516.x.

Ishikawa S, Suzui N, Ito-Tanabata S, Ishii S, Igura M, Abe T, Kuramata M, Kawachi N, Fujimaki S (2011) Real-time imaging and analysis of differences in cadmium dynamics in rice cultivars (Oryza sativa) using positron-emitting ${ }^{107} \mathrm{Cd}$ tracer. BMC Plant Biol 11:172. doi:10.1186/14712229-11-172. doi:10.1186/1471-2229-11-172

Ishimaru Y, Suzuki M, Tsukamoto T, Suzuki K, Nakazono M, Kobayashi T, Wada Y, Watanabe S, Matsuhashi S, Takahashi M, Nakanishi H, Mori S, Nishizawa NK (2006) Rice plants take up iron as an $\mathrm{Fe}^{3+}$-phytosiderophore and as $\mathrm{Fe}^{2+}$. Plant J 45:335-346. doi:10.1111/j.1365-313X.2005.02624.X.

Ito H, limura K (1976) The absorption and translocation of cadmium in rice plants and its influence on their growth, in comparison with zinc: Studies on heavy metal pollution of soils (Part 1). Bull Hokuriku Natl Agric Exp Stn 19:71-139

Jarup L, Akesson A (2009) Current status of cadmium as an environmental health problem. Toxicol Appl Pharm 238:201-208. doi:10.1016/j.taap.2009.04.020.

Jin T, Nordberg M, Frech W, Dumont X, Bernard A, Ye TT, Kong Q, Wang Z, Li P, Lundström NG, Li Y, Nordberg GF (2002) Cadmium biomonitoring and renal dysfunction among a population environmentally exposed to cadmium from smelting in China (ChinaCad). BioMetals 15:397-410. doi:10.1023/ A:1020229923095.

Kato M, Ishikawa S, Inagaki K, Chiba K, Hayashi H, Yanagisawa S, Yoneyama T (2010) Possible chemical forms of cadmium and varietal differences in cadmium concentrations in the phloem sap of rice plants (Oryza sativa L.). Soil Sci Plant Nutr 56:839-847. doi:10.1111/j.1747-0765.2010.00514.x.

Keller A, Schulin R (2003) Modelling heavy metal and phosphorus balances for farming systems. Nutr Cycl Agroecosys 66:271-284. doi:10.1023/ A:1024410126924.

Kikuchi T, Okazaki M, Toyota K, Motobayashi T, Kato M (2007) The input-output balance of cadmium in a paddy field of Tokyo. Chemosphere 67:920-927. doi:10.1016/j.chemosphere.2006.11.018.

Kim DY, Bovet L, Maeshima M, Martinoia E, Lee YS (2007) The ABC transporter AtPDR8 is a cadmium extrusion pump conferring heavy metal resistance. Plant J 50:207-218. doi:10.1111/j.1365-313X.2007.03044.X.

Kuramata M, Masuya S, Takahashi Y, Kitagawa E, Inoue C, Ishikawa S, Youssefian S, Kusano T (2009) Novel cysteine-rich peptides from Digitaria ciliaris and Oryza sativa enhance tolerance to cadmium by limiting its cellular accumulation. Plant Cell Physiol 50:106-117. doi:10.1093/pcp/pcn175.

Lee S, An G (2009) Over-expression of OsIRT1 leads to increased iron and zinc accumulations in rice. Plant Cell Environ 32:408-416. doi:10.1111/j.13653040.2009.01935.x

Li ZS, Lu YP, Zhen RG, Szczypka M, Thiele DJ, Rea PA (1997) A new pathway for vacuolar cadmium sequestration in Saccharomyces cerevisiae: YCF1-catalyzed transport of bis(glutathionato)cadmium. PNAS 94:42-47. doi:10.1073/ pnas.94.1.42.

Makino T, Takano H, Kamiya T, Itou T, Sekiya N, Inahara M, Sakurai Y (2008) Restoration of cadmium-contaminated paddy soils by washing with ferric chloride: $\mathrm{Cd}$ extraction mechanism and bench-scale verification. Chemosphere 70:1035-1043. doi:10.1016/j.chemosphere.2007.07.080. 
Miyadate H, Adachi S, Hiraizumi A, Tezuka K, Nakazawa N, Kawamoto T, Katou K, Kodama I, Sakurai K, Takahashi H, Satoh-Nagasawa N, Watanabe A,

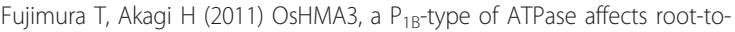
shoot cadmium translocation in rice by mediating efflux into vacuoles. New Phytol 189:190-199. doi:10.1111/j.1469-8137.2010.03459.x.

Mori S, Uraguchi S, Ishikawa S, Arao T (2009) Xylem loading process is a critical factor in determining $\mathrm{Cd}$ accumulation in the shoots of Solanum melongena and Solanum torvum. Environ Exp Bot 67:127-132. doi:10.1016/j. envexpbot.2009.05.006.

Murakami M, Nakagawa F, Ae N, Ito M, Arao T (2009) Phytoextraction by rice capable of accumulating $\mathrm{Cd}$ at high levels: reduction of $\mathrm{Cd}$ content of rice grain. Environ Sci Tech 43:5878-5883. doi:10.1021/es8036687.

Nakanishi H, Ogawa I, Ishimaru Y, Mori S, Nishizawa NK (2006) Iron deficiency enhances cadmium uptake and translocation mediated by the $\mathrm{Fe}^{2+}$ transporters OsIRT1 and OsIRT2 in rice. Soil Sci Plant Nutr 52:464-469. doi:10.1111/j.1747-0765.2006.00055.x.

Nebert DW, He L, Wang B, Hay EB (2009) Discovery of ZIP transporters that participate in cadmium damage to testis and kidney. Toxicol Appl Pharm 238:250-257. doi:10.1016/j.taap.2009.02.017.

Nordberg GF, Jin T, Kong Q, Ye T, Cai S, Wang Z, Zhuang F, Wu X (1997) Biological monitoring of cadmium exposure and renal effects in a population group residing in a polluted area in China. Sci Total Environ 199:111-114. doi:10.1016/50048-9697(97)05486-7.

Oda K, Otani M, Uraguchi S, Akihiro T, Fujiwara T (2011) Rice ABCG43 is Cd inducible and confers $\mathrm{Cd}$ tolerance on yeast. Biosci Biotech Biochem 75:1211-1213. doi:10.1271/bbb.110193.

Park J, Song WY, Ko D, Eom Y, Hansen TH, Schiller M, Lee TG, Martinoia E, Lee YS (2012) The phytochelatin transporters AtABCC1 and AtABCC2 mediate tolerance to cadmium and mercury. Plant J 69:278-288. doi:10.1111/j.1365313X.2011.04789.X.

Prévéral S, Gayet L, Moldes C, Hoffmann J, Mounicou S, Gruet A, Reynaud F, Lobinski R, Verbavatz JM, Vavasseur A, Forestier C (2009) A common highly conserved cadmium detoxification mechanism from bacteria to humans. J Biol Chem 284:4936-4943

Reeves PG, Chaney RL (2008) Bioavailability as an issue in risk assessment and management of food cadmium: A review. Sci Total Environ 398:13-19. doi:10.1016/j.scitotenv.2008.03.009.

Rodda M, Li G, Reid R (2011) The timing of grain Cd accumulation in rice plants: the relative importance of remobilisation within the plant and root $\mathrm{Cd}$ uptake post-flowering. Plant Soil 347:105-114. doi:10.1007/s11104-011-0829-4.

Romheld V, Marschner H (1986) Evidence for a specific uptake system for iron phytosiderophores in roots of grasses. Plant Physiol 80:175-180. doi:10.1104/ pp.80.1.175

Shimo H, Ishimaru Y, An G, Yamakawa T, Nakanishi H, Nishizawa NK (2011) Low cadmium (LCD), a novel gene related to cadmium tolerance and accumulation in rice. J Exp Bot 62(15):5727-5734

Shimbo S, Zhang ZW, Watanabe T, Nakatsuka H, Matsuda-Inoguchi N, Higashikawa K, Ikeda M (2001) Cadmium and lead contents in rice and other cereal products in Japan in 1998-2000. Sci Total Environ 281:165-175. doi:10.1016/50048-9697(01)00844-0.

Takahashi R, Ishimaru Y, Senoura T, Shimo H, Ishikawa S, Arao T, Nakanishi H, Nishizawa NK (2011) The OsNRAMP1 iron transporter is involved in Cd accumulation in rice. J Exp Bot 62:4843-4850. doi:10.1093/jxb/err136.

Takeda A, Kimura K, Yamasaki S (2004) Analysis of 57 elements in Japanese soils, with special reference to soil group and agricultural use. Geoderma 119:291-307. doi:10.1016/.geoderma.2003.08.006.

Tanaka K, Fujimaki S, Fujiwara T, Yoneyama T, Hayashi H (2007) Quantitative estimation of the contribution of the phloem in cadmium transport to grains in rice plants (Oryza sativa L.). Soil Sci Plant Nutr 53:72-77. doi:10.1111/j.17470765.2007.00116.x.

Tezuka K, Miyadate H, Katou K, Kodama I, Matsumoto S, Kawamoto T, Masaki S, Satoh H, Yamaguchi M, Sakurai K, Takahashi H, Satoh-Nagasawa N, Watanabe A, Fujimura T, Akagi H (2010) A single recessive gene controls cadmium translocation in the cadmium hyperaccumulating rice cultivar ChoKo-Koku. Theor Appl Genet 120:1175-1182. doi:10.1007/s00122-009-1244-6.

Thomine S, Wang RC, Ward JM, Crawford NM, Schroeder JI (2000) Cadmium and iron transport by members of a plant metal transporter family in Arabidopsis with homology to Nramp genes. PNAS 97:4991-4996. doi:10.1073/ pnas.97.9.4991.

Tommasini R, Evers R, Vogt E, Mornet C, Zaman GJR, Schinkel AH, Borst P, Martinoia $E$ (1996) The human multidrug resistance-associated protein functionally complements the yeast cadmium resistance factor 1. PNAS 93:6743-6748. doi:10.1073/pnas.93.13.6743.

Tsukahara T, Ezaki T, Moriguchi J, Furuki K, Shimbo S, Matsuda-Inoguchi N, Ikeda M (2003) Rice as the most influential source of cadmium intake among general Japanese population. Sci Total Environ 305:41-51. doi:10.1016/S00489697(02)00475-8.

Ueno D, Kono I, Yokosho K, Ando T, Yano M, Ma JF (2009) A major quantitative trait locus controlling cadmium translocation in rice (Oryza sativa). New Phytol 182:644-653. doi:10.1111/j.1469-8137.2009.02784.x.

Ueno D, Yamaji N, Kono I, Huang CF, Ando T, Yano M, Ma JF (2010) Gene limiting cadmium accumulation in rice. PNAS 107:16500-16505. doi:10.1073/ pnas. 1005396107

Ueno D, Koyama E, Yamaji N, Ma JF (2011) Physiological, genetic, and molecular characterization of a high-Cd-accumulating rice cultivar, Jarjan. J Exp Bot 62:2265-2272. doi:10.1093/jxb/erq383.

Uraguchi S, Kamiya T, Sakamoto T, Kasai K, Sato Y, Nagamura Y, Yoshida A, Kyozuka J, Ishikawa S, Fujiwara T (2011) Low-affinity cation transporter (OsLCT1) regulates cadmium transport into rice grains. PNAS 108:20959-20964. doi:10.1073/pnas.1116531109.

Uraguchi S, Kiyono M, Sakamoto T, Watanabe I, Kuno K (2009) Contributions of apoplasmic cadmium accumulation, antioxidative enzymes and induction of phytochelatins in cadmium tolerance of the cadmium-accumulating cultivar of black oat (Avena strigosa Schreb.). Planta 230:267-276. doi:10.1007/s00425009-0939-x.

Uraguchi S, Mori S, Kuramata M, Kawasaki A, Arao T, Ishikawa S (2009) Root-toshoot $\mathrm{Cd}$ translocation via the xylem is the major process determining shoot and grain cadmium accumulation in rice. J Exp Bot 60:2677-2688. doi:10.1093/jxb/erp119.

Vatamaniuk OK, Bucher EA, Sundaram MV, Rea PA (2005) CeHMT-1, a putative phytochelatin transporter, is required for cadmium tolerance in Caenorhabditis elegans. J Biol Chem 280:23684-23690. doi:10.1074/jbc. M503362200.

Verret F, Gravot A, Auroy P, Leonhardt N, David P, Nussaume L, Vavasseur A, Richaud P (2004) Overexpression of AtHMA4 enhances root-to-shoot translocation of zinc and cadmium and plant metal tolerance. FEBS Lett 576:306-312. doi:10.1016/j.febslet.2004.09.023.

Vert G, Grotz N, Dedaldechamp F, Gaymard F, Guerinot ML, Briat JF, Curie C (2002) IRT1, an Arabidopsis transporter essential for iron uptake from the soil and for plant growth. Plant Cell 14:1223-1233. doi:10.1105/tpc.001388.

Wagner GJ (1993) Accumulation of cadmium in crop plants and its consequences to human health. Adv Agron 51:173-212

Watanabe T, Shimbo S, Moon CS, Zhang ZW, Ikeda M (1996) Cadmium contents in rice samples from various areas in the world. Sci Total Environ 184:191-196. doi:10.1016/0048-9697(96)05100-5.

Watanabe T, Zhang ZW, Moon CS, Shimbo S, Nakatsuka H, Matsuda-Inoguchi N, Higashikawa K, Ikeda M (2000) Cadmium exposure of women in general populations in Japan during 1991-1997 compared with 1977-1981. Int Arch Occ Env Hea 73:26-34. doi:10.1007/PL00007934.

Wolnik KA, Fricke FL, Capar SG, Braude GL, Meyer MW, Satzger RD, Bonnin E (1983) Elements in major raw agricultural crops in the United States. 1 Cadmium and lead in lettuce, peanuts, potatoes, soybeans, sweet corn, and wheat J Agr Food Chem 31:1240-1244

Wong C KE, Cobbett CS (2009) HMA P-type ATPases are the major mechanism for root-to-shoot Cd translocation in Arabidopsis thaliana. New Phytol 181:71-78. doi:10.1111/j.1469-8137.2008.02638.x.

Xian X (1988) Distribution of cadmium and zinc in field and paddy field soils near a zinc smelter. J Env Sci Heal A 23:157-167. doi:10.1080/ 10934528809375400.

Yamagata N, Shigematsu I (1970) Cadmium pollution in perspective. Bull Inst Pub Heal 19:1-27

doi:10.1186/1939-8433-5-5

Cite this article as: Uraguchi and Fujiwara: Cadmium transport and tolerance in rice: perspectives for reducing grain cadmium accumulation. Rice 2012 5:5. 